\title{
Protektivitas, Reaksi Lokal, dan Reaksi Sistemik setelah Imunisasi dengan Vaksin Td pada Anak Sekolah Dasar di Indonesia
}

\author{
Julitasari Sundoro, Novilia Sjafri Bachtiar, Syafriyal, Rini Mulia Sari \\ Komite Nasional Pengkajian dan Penanggulangan Kejadian Ikutan Paska Imunisasi Jakarta
}

\begin{abstract}
Abstrak
Vaksin Td diberikan untuk melindungi populasi usia 7 tahun atau lebih dari penyakit tetanus dan difteria. Tujuan penelitian ini adalah untuk mengetahui reaksi dan respons imun setelah memperoleh 1 dosis vaksin Td. Penelitian ini merupakan post marketing surveillance, dengan desain kohort pada anak sekolah dasar di Jawa Timur. Reaksi lokal dan sistemik dicatat pada kartu harian hingga 28 hari setelah imunisasi. Darah diambil sebelum dan 28 hari setelah imunisasi. Pengukuran antibodi menggunakan metode uji double antigen ELISA, dengan batas proteksi $0,01 \mathrm{IU} / \mathrm{mL}$ baik untuk antitetanus maupun antidifteria. Pengamatan yang berlangsung dari Oktober 2010 hingga April 2011 ini melibatkan sebanyak 2.978 anak sekolah dasar, termasuk 159 anak untuk kelompok respons imun. Sebanyak 1,18-2,45\% anak mengalami demam dengan instensitas mayoritas ringan. Reaksi lokal terbanyak adalah nyeri pada 30 menit setelah imunisasi $62,49 \%$ naik menjadi $83,38 \%$ pada hari ke-1, dan menurun pada hari berikutnya dengan intensitas mayoritas adalah ringan. Tidak ditemukan kejadian pascaimunisasi serius. Sebanyak 98,11\% dan 99,37\% anak terlindungi terhadap difteria dan tetanus dengan geometric mean titer 1,2280 IU/mL $(\mathrm{p}=0,000)$ untuk antidifteria dan $10,6068 \mathrm{IU} / \mathrm{mL}(\mathrm{p}=0,009)$ untuk antitetanus. Simpulan, dari hasil pengamatan menunjukkan bahwa vaksin ini bersifat imunogenik dan aman setelah pemberian 1 (satu) dosis pada anak sekolah dasar. [MKB. 2014;46(3):155-61]
\end{abstract}

Kata kunci: Post marketing surveillance (PMS), reaksi lokal, reaksi sistemik, vaksin Td

\section{Protectivity, Local Reaction, and Systemic Reaction Following Td Vaccination among Elementary School Students in Indonesia}

\begin{abstract}
Td vaccine is given to provide protection to tetanus and diphtheria in children 7 years old or above. The objective of this study was to evaluate the reactions and immune response after 1 dose of Td vaccine. This study was a post-marketing surveillance with a cohort design among elementary school students in East Java. Systemic and local reactions were recorded in diary cards untill 28 days after immunization. Blood was collected before and 28 days after immunization. Antibody titers were measured using double antigen ELISA with a cut off protection rate $\geq 0.01 \mathrm{IU} / \mathrm{ml}$. Observation were performed between October 2010 and April 2011 which involved 2,978 elementary school students, including 159 subjects for the immune response group. In this study, fever occured in $1.18-2.45 \%$ subjects at the first three days with mild intensity and it resolved immediately without any medication. The most frequently found local reaction was pain in $62.49 \%$ subjects at 30 minutes after injection and increased to $83.38 \%$ at day 1 after immunization. The pain decreased the day after, with mostly mild intensity. No serious adverse reaction was found. It was found that $98.11 \%$ and $99.37 \%$ subjects were protected from diphtheria and tetanus with a Geometric Mean Titer of $12280 \mathrm{IU} / \mathrm{mL}(\mathrm{p}=0.000)$ for anti diphtheria and $10.6068 \mathrm{IU} / \mathrm{mL}(\mathrm{p}=0.009)$ for anti tetanus. Therefore, it is concluded that $\mathrm{Td}$ vaccine is safe and immunogenic after one dose in school age children without any serious adverse event. [MKB. 2014;46(3):155-61]
\end{abstract}

Key words: Local reactions, post marketing surveillance (PMS), systemic reactions, Td vaccine

Korespondensi: Dr. Julitasari Sundoro, dr., Msc-PH, Sekertariat Komite Nasional Pengkajian dan Penanggulangan Kejadian Ikutan Paska Imunisasi (Komnas PP KIPI), Jalan Percetakan Negara No. 29 Jakarta Pusat, mobile 0811142047, e-mail julitasari. sundoro@gmail.com 


\section{Pendahuluan}

Vaksin memiliki peran penting dalam pencegahan dan pengendalian penyakit menular. Hasil kajian UNICEF menunjukkan korelasi terbalik antara cakupan vaksin dari sebuah populasi dan tingkat kematian anak di bawah 5 (lima) tahun. Vaksin tidak hanya efektif dalam mengurangi angka kejadian penyakit dan kematian akibat penyakit menular, tetapi penggunaannya dapat mengurangi biaya perawatan kesehatan secara langsung maupun tidak langsung. ${ }^{1}$

Pada saat epidemi difteria di Eropa dan Amerika Serikat pada tahun 1980-an, case fatality rate mencapai 50\%, dan angka ini menurun menjadi $15 \%$ sesudah penggunaan antitoksin sebagai pengobatan. Setelah era vaksinasi menggunakan toksoid difteria, di negera maju umumnya endemi difteria sudah tidak ada dan sangat jarang, namun cakupan imunisasi tetap harus dijaga dengan baik, dengan timbulnya berbagai wabah difteria di berbagai bagian dunia seperti di Uni Soviet pada tahun 1990 -an. ${ }^{2}$

Pada tahun 2011 kasus difteria mulai meningkat di Indonesia, khususnya di Provinsi Jawa Timur. Sampai dengan 20 Oktober 2012, jumlah kasus difteria di Jawa Timur mencapai 710 penderita dan 28 di antaranya meninggal dunia. Pada tahun 2011, angka kejadian tertinggi di Kota Malang. Pada tahun 2012, kasus terbanyak di Kabupaten Situbondo yaitu 113 kasus, dengan meninggal 7 kasus, disusul Kabupaten Jombang 87 kasus, meninggal 11 kasus. $^{3}$

Di Indonesia insidensi penyakit tetanus itu menurun setiap tahun. Pada tahun 2000-2002 insidensi tetanus pada seluruh rumah sakit di Indonesia untuk pasien rawat inap pada usia 1544 tahun $(43,34 \%)$ dan usia $>45$ tahun $(44,16 \%)$ untuk pasien rawat inap. Semua ini sangat terkait dengan imunisasi yang tidak adekuat. ${ }^{4}$

Meskipun dampak program imunisasi skala besar telah secara bermakna mengurangi angka kejadian penyakit, kejadian luar biasa (KLB) masih saja terjadi di daerah, dengan imunisasi pada bayi belum merata, dan proteksi yang ditimbulkan oleh vaksinasi dasar tidak dapat bertahan lama, sehingga diperlukan booster, yang dalam penelitian ini dapat diantisipasi dengan pemberian vaksin Td 1 dosis pada anak sekolah dasar.

Mengacu pada rekomendasi Komisi Penasihat Ahli Imunisasi Nasional/Technical Advisory Group on Immunization (TAG) No. 67/TAG/ $\mathrm{XI} / 2008$ bahwa; perlunya diberikan vaksin difteria sebagai penguat booster pada anak sekolah untuk pencegahan penyakit difteria, sesuai dengan jadwal yang telah berlaku untuk Bulan Imunisasi Anak Sekolah (BIAS), vaksin DT diberikan pada anak sekolah kelas satu dan penggunaan vaksin pada anak kelas dua dan kelas tiga Sekolah Dasar adalah dengan vaksin $\mathrm{Td}$ dengan kandungan difteria yang lebih kecil, karena vaksin DT tidak boleh diberikan pada anak di atas 7 tahun. Awal peralihan vaksin TT menjadi Td dapat diterapkan di daerah dengan risiko tinggi KLB difteria yaitu Provinsi Jawa Timur yang memiliki data dasar lengkap, selanjutnya penggunaan vaksin Td dapat diperluas sesuai kebutuhan. Perlu diadakan suatu studi pascapemasaran vaksin yang memperoleh izin edar pada tahun 2008.

\section{Metode}

Penelitian ini adalah post marketing surveillance dengan desain kohort terhadap 3.000 anak sekolah di Provinsi Jawa Timur pada periode Oktober 2010 hingga April 2011. Persetujuan Etik telah diperoleh dari Komite Etik Penelitian Kesehatan Fakultas Kedokteran UI-RSCM, Jakarta.

Anak sekolah dasar (SD) yang terlibat dalam penelitian ini berasal dari 3 kabupaten di Provinsi Jawa Timur, yaitu Kabupaten Mojokerto, Gresik dan Pamekasan, dengan masing-masing 1.000 anak SD dari setiap kabupaten. Provinsi Jawa Timur dipilih berdasarkan respons kejadian luar biasa (KLB) untuk pemberian imunisasi difteria. Pengamatan yang disertai dengan pengambilan darah terhadap 150 anak hanya dilakukan di Kabupaten Mojokerto berdasarkan kesesuaian jumlah murid dan lokasi yang memadai untuk pengambilan dan pengiriman darah sebelum dan sesudah imunisasi.

Setiap subjek yang ikut dalam penelitian akan menerima 1 (satu) dosis $(0,5 \mathrm{~mL})$ vaksin $\mathrm{Td}$ produksi PT Bio Farma dengan nomor batch 041019. Reaksi lokal dan sistemik dicatat pada kartu harian pada 30 menit, 1, 2 dan 3 hari dan hingga 28 hari setelah imunisasi. Reaksi lokal merupakan reaksi yang timbul pada dan sekitar tempat suntikan. Reaksi lokal yang diperhatikan adalah rasa nyeri, kemerahan, pembengkakan pada bekas suntikan, serta reaksi lokal lainnya yang dikategorikan ringan, sedang, dan berat berdasarkan ukuran diameter terlebar $<2,5 \mathrm{~cm}$, $2,5-5 \mathrm{~cm}$, dan $>5 \mathrm{~cm}$. Derajat nyeri dikategorikan berdasarkan: ringan (nyeri bila tempat suntikan disentuh), sedang (nyeri bila lengan digerakkan), dan berat (nyeri dalam keadaan istirahat). ${ }^{5}$

Reaksi sistemik merupakan semua reaksi yang terjadi secara sistemik pascaimunisasi. Pada literatur WHO mengenai "Supplementary Information on Vaccine Safety" dinyatakan bahwa reaksi sistemik termasuk demam, nyeri otot, dan sakit kepala. ${ }^{6}$ Selanjutnya pengukuran suhu tubuh yang dilakukan dikategorikan menjadi demam 
ringan $\left(38,0-38,4^{\circ} \mathrm{C}\right)$, demam sedang $(38,5-38,9$ $\left.{ }^{\circ} \mathrm{C}\right)$, dan demam tinggi $\left(\geq 39,0^{\circ} \mathrm{C}\right)$. Reaksi sistemik lainnya diukur berdasarkan intensitasnya, ringan bila tidak mengganggu aktivitas, sedang bila terkadang mengganggu aktivitas, dan berat bila menghambat aktivitas seharian. ${ }^{5}$

Pengamatan reaksi yang timbul dilakukan oleh orangtua dan dikonfirmasi oleh guru kelas, dengan pencatatan pada Kartu Harian Anak (KHA). Darah vena diambil sebelum dan 28 hari setelah imunisasi khusus pada kelompok respons imun. Darah diolah menjadi serum dan disimpan pada suhu $-20{ }^{\circ} \mathrm{C}$ di Balai Besar Laboratorium Kesehatan Surabaya, untuk kemudian dikirim ke Bio Farma. Pengukuran antibodi terhadap tetanus dan difteria menggunakan metode uji double antigen ELISA yang dilakukan di laboratorium Uji Klinis PT Bio Farma, dengan batas proteksi $0,01 \mathrm{IU} / \mathrm{mL}$ baik untuk antitetanus maupun antidifteria. ${ }^{4,6,7}$ Pengujian ini telah divalidasi dan hasil validasi disetujui oleh quality assurance PT Bio Farma.

Persentase subjek yang mengalami reaksi lokal dan sistemik dihitung berdasarkan waktu timbulnya. Persentase subjek yang mempunyai antibodi protektif pascaimunisasi lalu dihitung dan geometric mean titer (GMT/nilai rata-rata geometris titer) yang dihasilkan dibandingkan antara pra dan pascaimunisasi mempergunakan perhitungan Kruskal Wallis.

\section{Hasil}

Dari 3.000 anak, berdasarkan validasi data pada Kartu Harian Anak, yang dapat dianalisis adalah 2.978 data anak, dengan proporsi yang hampir sama untuk tiap sekolah.

Imunisasi Td diberikan pada anak SD/MI Kelas II dan III menggantikan vaksin TT sesuai jadwal imunisasi BIAS (Bulan Imunisasi Anak Sekolah). Usia rata-rata anak yang mendapatkan imunisasi $\mathrm{Td}$ itu sebesar $\pm 8,65$ tahun dengan simpangan baku 0,854 .

Berdasarkan informasi yang didapatkan dari orangtua diketahui anak yang telah imunisasi DT 46,5\% (37,4\%:1 kali dan 8,1\%:2 kali) dan 54,4\% menyatakan belum pernah atau tidak tahu.

Seharusnya ketika bayi, anak sudah mendapat imunisasi difteria melalui imunisasi DTP/HB sebanyak tiga kali. Dari hasil wawancara melalui pengisian KHA oleh orangtua diketahui riwayat imunisasi DTP/HB lengkap 51,8\%, DTP/HB 1 kali $10,2 \%$, dan terdapat $37,9 \%$ yang tidak diketahui riwayat imunisasi DTP/HB-nya.

Pada pengamatan reaksi sistemik dan lokal,

Tabel 1 Karakteristik Anak

\begin{tabular}{lccc}
\hline \multicolumn{2}{c}{ Variabel } & $\mathbf{n}$ & $\mathbf{\%}$ \\
\hline Usia (tahun) & & & \\
& 7 & 214 & 7,2 \\
& 8 & 1.088 & 36,5 \\
& 9 & 1.214 & 40,8 \\
& 10 & 437 & 14,7 \\
& 11 & 18 & 0,6 \\
& 12 & 6 & 0,2 \\
\multicolumn{1}{c}{ Riwayat imunisasi DT } & 1 & 0,0 \\
1 kali & & 1.115 & 37,4 \\
2 kali & 242 & 8,1 \\
Tidak tahu & 1.621 & 54,4 \\
Riwayat imunisasi DPT/HB & & 10,2 \\
1 kali & 3.03 & 0,1 \\
2 kali & 3 & 51,8 \\
3 kali & 1.544 & 37,9 \\
Tidak tahu & 1.128 & 100 \\
Total & 2.978 &
\end{tabular}


Julita S.: Protektivitas, Reaksi Lokal, dan Reaksi Sistemik setelah Imunisasi dengan Vaksin Td pada Anak Sekolah Dasar

Tabel 2 Reaksi Sistemik Demam Setelah Imunisasi Td

\begin{tabular}{|c|c|c|c|c|c|c|c|c|c|c|}
\hline \multirow{2}{*}{$\begin{array}{c}\text { Kondisi Suhu } \\
\text { Tubuh }\end{array}$} & \multicolumn{2}{|c|}{30 Menit } & \multicolumn{2}{|c|}{1 Hari } & \multicolumn{2}{|c|}{2 Hari } & \multicolumn{2}{|c|}{3 Hari } & \multicolumn{2}{|c|}{ 4-28 Hari } \\
\hline & n & $\%$ & $\mathbf{n}$ & $\%$ & $\mathbf{n}$ & $\%$ & $\mathbf{n}$ & $\%$ & n & $\%$ \\
\hline Demam ringan & 23 & 0,772 & 50 & 1,679 & 43 & 1,444 & 30 & 1,007 & 32 & 1,075 \\
\hline Demam sedang & 11 & 0,369 & 6 & 0,2 & 8 & 0,269 & 11 & 0,369 & 4 & 0,134 \\
\hline Demam tinggi & 1 & 0,034 & 17 & 0,571 & 9 & 0,3 & 9 & 0,3 & 8 & 0,269 \\
\hline Total & 35 & 1,18 & 73 & 2,45 & 60 & 2,01 & 50 & 1,68 & 44 & 1,48 \\
\hline
\end{tabular}

Keterangan: Demam ringan $38-38,5^{\circ} \mathrm{C}$, demam sedang $>38,5-39^{\circ} \mathrm{C}$, demam tinggi $>39^{\circ} \mathrm{C}$

dari 2.978 anak yang diamati reaksi sistemik melalui pengukuran suhu tubuh mulai dari 30 menit sampai hari ke-28 pascaimunisasi diketahui seperti pada Tabel 2. Pengukuran suhu tubuh yang dilakukan tersebut selanjutnya dikategorikan menjadi demam ringan $\left(38,0-38,4{ }^{\circ} \mathrm{C}\right)$, demam sedang $\left(38,5-38,9^{\circ} \mathrm{C}\right)$, dan demam tinggi $(\geq 39,0$ $\left.{ }^{\circ} \mathrm{C}\right)$.

Dari pengukuran terhadap suhu tubuh anak setelah imunisasi sejak 30 menit sampai 28 hari pascaimunisasi diketahui berkisar antara 1,18\% hingga 2,45\% kejadian demam, dengan angka tertinggi terjadi pada hari ke-1 sebanyak 2,45\%. Jumlah subjek yang mengalami demam tinggi adalah $0,571 \%$ pada hari ke-1 dan menurun menjadi $0,3 \%$ pada hari ke-2. Reaksi sistemik lainnya sangat jarang, paling tinggi adalah pusing pada hari ke-1 sebanyak 11 orang atau $0,37 \%$.

Reaksi lokal pascaimunisasi Td yang paling banyak ditemukan adalah nyeri pada tempat suntikan. Diketahui kejadian nyeri lokal paling banyak adalah pada hari ke-1 yaitu sebesar $83,38 \%$ (2.483 anak) selanjutnya menurun dan pada pengamatan hari ke-4 28, insidensi sudah jauh berkurang, hanya ada 11 kasus $(0,37 \%)$. Dapat dilihat bahwa mayoritas nyeri yang timbul adalah kategori ringan. Reaksi lokal lainnya yang ditemukan adalah kemerahan pada tempat suntikan sebanyak $13,6 \%$ dan pembengkakan $9,7 \%$ pada hari pertama, yang semuanya menurun pada hari kedua dan mayoritas dengan intensitas ringan, dan sembuh tanpa pengobatan. Selama pengamatan tidak ditemukan reaksi sistemik yang serius.

Setelah divalidasi akhirnya didapat 159 sampel yang valid lalu dilakukan pengujian laboratorium. Jumlah subjek lebih daripada yang direncanakan sebelumnya pada protokol karena menyesuaikan dengan jumlah anak per sekolah.

Hasil titer antibodi difteria sebelum imunisasi Td, 127 anak $(79,87 \%)$ protektif terhadap difteria dan 155 anak $(97,48 \%)$ protektif terhadap tetanus. Satu bulan setelah imunisasi Td, sebanyak 156 anak $(98,11 \%)$ protektif terhadap difteria dan $158(99,37 \%)$ anak protektif terhadap tetanus. Serokonversi (transisi dari seronegatif menjadi seropositif) untuk titer antibodi difteria adalah $90,63 \%$ dan $75 \%$ untuk tetanus.

Mengacu kepada standar titer minimal yang memberikan perlindungan jangka panjang $(\geq 0.1$ $\mathrm{IU} / \mathrm{mL}$ ) diketahui untuk titer antibodi difteria mengalami kenaikan dari praimunisasi 87 anak

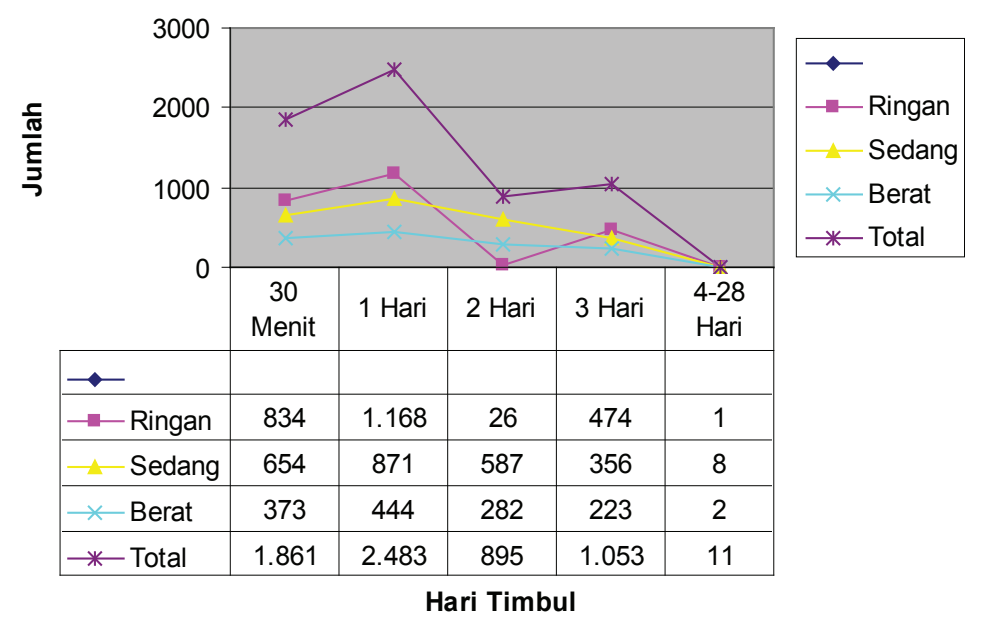

Gambar 1 Grafik Nyeri pada Tempat Suntikan Menurut Waktu Timbul dan Intensitas 
Tabel 3 Titer Serologi Difteria dan Tetanus Pra dan Pascaimunisasi Td

\begin{tabular}{lcccc}
\hline \multirow{2}{*}{$\begin{array}{c}\text { Jenis } \\
\text { Antibodi }\end{array}$} & \multicolumn{2}{c}{ Praimunisasi } & \multicolumn{2}{c}{ Pascaimunisasi } \\
\cline { 2 - 5 } & $\mathbf{n}$ & $\mathbf{\%}$ & $\mathbf{n}$ & $\mathbf{\%}$ \\
\hline Difteria & 127 & 79,9 & 156 & 98,1 \\
Tetanus & 155 & 97,5 & 158 & 99,4 \\
\hline
\end{tabular}

$(54,72 \%)$ ke pascaimunisasi menjadi 140 anak $(88,05 \%)$. Untuk tetanus, diketahui untuk titer antibodi mengalami kenaikan dari praimunisasi 143 anak $(89,94 \%)$ ke pascaimunisasi menjadi 154 anak $(99,37 \%)$.

Terlihat peningkatan geometric mean titer (GMT) difteria dari praimunisasi sebesar 0,1598 ke pascaimunisasi 1,2280 naik sebanyak 7,6862 kali, untuk tetanus dari 1,8616 menjadi 10,6068 naik sebanyak 5,6976 kali dari praimunisasi (Tabel 3).

Titer antibodi difteria pra dan pascaimunisasi diketahui bahwa nilai perbedaan sebesar 0,000 $(p<0,05)$, yang berarti terdapat perbedaan titer antibodi rata-rata yang sangat bermakna dari pra terhadap pascaimunisasi dengan nilai interval kepercayaan 95\% adalah -80,519 sampai -50,128. Hasil ini memperlihatkan terdapat peningkatan yang sangat bermakna dari pra ke pascaimunisasi difteria terhadap subjek.

Titer antibodi tetanus pra dan pascaimunisasi diketahui nilai perbedaannya $0,009 \quad(p<0,005)$, yang berarti terdapat perbedaan titer antibodi rata-rata yang sangat bermakna dari pra terhadap pascaimunisasi dengan nilai interval kepercayaan $95 \%$ adalah $-11,062$ sampai $-1,566$. Hasil ini menunjukkan terdapat peningkatan yang sangat bermakna dari pra ke pascaimunisasi tetanus terhadap anak. Meskipun lebih dari $90 \%$ anak sudah protektif terhadap tetanus sebelum booster, namun pemberian 1 (satu) booster vaksin $\mathrm{Td}$ secara signifikan menaikkan titer antibodi.

\section{Pembahasan}

Dari 2.978 anak yang diamati, tidak ditemukan kejadian ikutan pascaimunisasi (KIPI) serius pada 30 menit pertama pascaimunisasi, maupun hingga 28 hari pascaimunisasi. Reaksi sistemik yang diukur antara lain demam melalui pengukuran suhu tubuh mulai dari 30 menit sampai hari ke-28 pascaimunisasi. Angka kejadian demam pada setiap kali pengamatan adalah bervariasi $1,148-2,45 \%$. Paling tinggi pada hari ke-1 pascaimunisasi dengan kategori ringan, yaitu 1,679\%.

Pada literatur WHO mengenai "Supplementary Information on Vaccine Safety" dinyatakan bahwa reaksi sistemik termasuk demam, nyeri otot, dan sakit kepala adalah $10 \%$ pascaimunisasi Td. ${ }^{8,9}$ Pada bridging study Td yang dilakukan pada tahun 2007 di Bandung, kejadian demam bervariasi antara $0,7 \%$ hingga $4,7 \%$, dengan demikian pada pengamatan kali ini sedikit lebih rendah dibandingkan dengan studi sebelumnya. ${ }^{10}$ Reaksi sistemik lainnya sangat jarang dengan angka kejadian antara 0,034\% hingga $0,37 \%$, yang terbanyak adalah pusing pada hari ke-1 yaitu sebanyak 11 orang $(0,37 \%)$. Sebuah studi di Spanyol terhadap 3.072 orang dewasa ditemukan reaksi sistemik berupa lemas $5,1 \%$ dan demam $1,7 \%$, angka yang sangat mirip dengan studi ini. ${ }^{11}$

Angka kejadian nyeri pada bekas suntikan bervariasi berdasarkan waktu timbul antara $0,37 \%$ hingga $83,38 \%$ dengan angka paling tinggi pada hari ke-1 pascaimunisasi. Mayoritas dari nyeri yang dirasakan termasuk dalam kategori ringan $39,22 \%$. Bila dibandingkan dengan data pada literatur (WHO) reaksi lokal ditemukan bervariasi $10-75 \%{ }^{8}$ Di sini angka yang ditemukan sedikit di atas literatur karena subjek yang berpartisipasi adalah pada kategori usia yang masih sangat muda dan sangat sensitif dengan rangsang nyeri. Pada penelitian sebelumnya menggunakan vaksin Td pada kelompok usia yang lebih besar (10-18 tahun), nyeri hanya ditemukan pada $20,3 \%$ subjek. ${ }^{10}$ Pada studi vaksin Td pada orang dewasa, nyeri hanya dilaporkan oleh $21 \%$ subjek. ${ }^{9}$ Studi pada orang dewasa yang lain menemukan nyeri lebih tinggi yaitu $43 \%$, namun tetap tidak setinggi yang ditemukan pada studi ini. ${ }^{11}$ Hal ini cukup wajar karena anak memang lebih sensitif dengan rangsang nyeri. Hal ini terlihat pada studi vaksin Td di Korea Selatan dengan membandingkan reaksi yang timbul pada anak praremaja dengan remaja, terlihat anak praremaja secara bermakna mengalami reaksi yang lebih banyak ditemukan pada kelompok usia lebih muda (praremaja) $(\mathrm{p}=0,006) \cdot{ }^{12}$

Angka kejadian kemerahan pada tempat bekas suntikan tertinggi pada hari ke-1 pascaimunisasi sebesar $13,09 \%$, dengan intensitas umumnya adalah ringan. Keadaan ini tidak jauh berbeda dari studi sebelumnya bahwa kemerahan ditemukan pada $14,2 \%,{ }^{10}$ namun pada studi vaksin Td yang lainnya pada orang dewasa ternyata didapatkan lebih tinggi, yaitu $50 \%{ }^{9}$

Pembengkakan terjadi pada $0,6-9,4 \%$, dengan kejadian paling tinggi adalah pada 1 (satu) hari pascaimunisasi. Umumnya merupakan kategori yang ringan dan sembuh sendiri tanpa pengobatan. Bila dibandingkan dengan hasil studi sebelumnya, pembengkakan ditemukan pada $12,7 \%$ subjek. ${ }^{10}$ Pada studi ini pembengkakan ditemukan sedikit di bawah studi sebelumnya, namun sedikit lebih tinggi bila dibandingkan dengan studi imunisasi masal vaksin Td di Spanyol, yaitu 3,8\%. ${ }^{11}$ 
Sebelum imunisasi, ditemukan 79,87\% anak mempunyai titer protektif terhadap difteria dan $97,48 \%$ anak mempunyai titer antibodi protektif terhadap tetanus, dengan GMT masing-masing $0,1598 \mathrm{IU} / \mathrm{mL}$ untuk difteria dan $1,8616 \mathrm{IU} / \mathrm{mL}$ untuk tetanus.

Satu bulan pascaimunisasi jumlah anak yang protektif terhadap difteria naik menjadi $98,11 \%$ dan terhadap tetanus juga naik menjadi 99,37\%, dengan nilai GMT menjadi 1,228 IU/mL untuk antibodi terhadap difteria dan 10,6068 IU/mL untuk antibodi terhadap tetanus, GMT masingmasing naik sebanyak 7,6862 kali dan 5,6976 kali untuk antibodi difteria dan tetanus. Angka seroproteksi ini mirip bila dibandingkan dengan studi lainnya di India dan Korea, 96-100\% anak mempunyai titer protektif baik terhadap difteria maupun tetanus. ${ }^{12,13}$

Sebanyak 20,13\% anak belum dapatterlindungi terhadap difteria praimunisasi. Keadaan ini tentu saja menyebabkan anak tersebut berisiko untuk tertulari penyakit difteria karena berdomisili di daerah dengan KLB (kejadian luar biasa) difteria. Apabila dibandingkan dengan penelitian sebelumnya di Bandung pada tahun 2007, hanya $14,2 \%$ anak yang tidak mempunyai kekebalan terhadap difteria dengan GMT $0,0618 \mathrm{IU} / \mathrm{mL}$. Berarti tingkat proteksi anak terhadap difteria di Kota Bandung lebih baik pada tahun 2007 bila dibandingkan dengan di Mojokerto tahun 2011 meskipun dengan GMT yang lebih rendah, karena studi dilakukan pada anak dengan kelompok usia lebih besar, dan jarak dengan imunisasi terakhir sudah cukup jauh. Berdasarkan survei pada studi ini ditemukan bahwa hanya $38 \%$ anak yang mengaku mendapat 1 (satu) dosis vaksin DT dan $8 \%$ anak mengaku menerima vaksin DT 2 dosis, sedangkan sisanya $54 \%$ menjawab tidak tahu. Berdasarkan studi vaksin DT di Bogor, 87,32\% anak masih mempunyai titer protektif untuk difteria praimunisasi DT (4-5 tahun setelah 3 dosis DTP). ${ }^{14}$ Hal ini menunjukkan bahwa pada studi ini kemungkinan memang sedikit sekali anak yang memperoleh imunisasi DT sebelumnya.

Setelah imunisasi $98,11 \%$ anak terlindungi dari difteria, namun masih terdapat 3 (tiga) anak $(1,89 \%)$ yang belum terlindungi. Hal ini dapat disebabkan karena kondisi individual anak dikarenakan status gizi, sistem imun, atau status imunisasinya yang masih kurang sehingga pemberian vaksin Td ini bukan bersifat sebagai booster melainkan sebagai imunisasi dasar. Dengan 1 dosis vaksin Td berhasil menimbulkan titer antibodi terhadap difteria yang tinggi $\geq 0,1$ $\mathrm{IU} / \mathrm{mL}$ (proteksi jangka panjang) dari hanya $45,28 \%$ menjadi $88,05 \%$. Hal ini menunjukkan selain menimbulkan proteksi, vaksin Td ini juga berhasil menginduksi titer yang tinggi. Bila dibandingkan dengan studi sebelumnya, jumlah anak yang terlindungi setelah 1 (satu) dosis vaksin Td adalah 99,3\%, dengan GMT 0,7583 IU/ $\mathrm{mL}$. GMT setelah imunsasi tidak setinggi studi di Mojokerto namun hal ini dapat disebabkan karena GMT praimunisasi di Mojokerto juga sudah tinggi $(0,1598 \mathrm{IU} / \mathrm{mL})$ dibandingkan dengan studi di Bandung $(0,0618 \mathrm{IU} / \mathrm{mL})$ meskipun jumlah yang mempunyai antibodi protektif lebih rendah.

Sebelum imunisasi dengan vaksin Td, tingkat proteksi terhadap tetanus sudah cukup tinggi untuk daerah Mojokerto, yaitu 97,48\%. Hal ini dapat disebabkan karena program imunisasi TT yang sudah sangat baik pada wanita usia subur dan ibu hamil, sehingga ketika baru lahirpun bayi sudah mempunyai titer terhadap tetanus yang cukup tinggi. Namun demikian, imunisasi Td juga memberikan manfaat bagi yang sudah terlindungi dengan kenaikan titer yang tinggi menjadi di atas $0,1 \mathrm{IU} / \mathrm{mL}$ (proteksi jangka panjang) yaitu dari $89,94 \%$ menjadi $99,37 \%$. Pada literatur dinyatakan bahwa dengan titer $\geq 0,1 \mathrm{IU} / \mathrm{mL}$ mampu memberikan proteksi jangka panjang. Namun demikian, serokonversi hanya $75 \%$ karena dari 4 subjek yang tidak protektif sebelum imunisasi, 1 subjek tetap tidak protektif pascaimunisasi. Sama halnya dengan antibodi difteria, keadaan ini dapat disebabkan oleh karena faktor individual ataupun status imunisasinya yang belum lengkap. Bila dibandingkan dengan studi di Bandung sebelumnya, 97,9\% anak telah mempunyai titer yang tinggi terhadap tetanus sebelum imunisasi, dan setelah imunisasi, $100 \%$ anak mempunyai titer $\geq 0,1 \mathrm{IU} / \mathrm{mL} .{ }^{11}$

Dari hasil di atas dapat ditarik kesimpulan bahwa vaksin Td yang dipergunakan pada anak sekolah dasar ini bersifat imunogenik dan aman karena menimbulkan reaksi lokal dan sistemik yang dapat ditoleransi setelah pemberian 1 (satu) dosis.

\section{Ucapan Terima Kasih}

Kami mengucapkan terima kasih atas bantuan dan kerja sama dari Dinas Kesehatan Provinsi Jawa Timur beserta jajarannya, juga dengan Komisi Daerah KIPI untuk wilayah Jawa Timur, serta anak-anak sekolah dasar di Mojokerto, Gresik, dan Pamekasan.

\section{Daftar Pustaka}

1. UNICEF. The state of the world's children, 1996. 50 ${ }^{\text {th }}$ Anniversary Edition (1946-1996). (diunduh 16 Januari 2013). Tersedia dari: http://www.UNICEF.org/sowc96/about.htm. 
2. World Health Organization. Weekly epidemiological record. Diphtheria-vaccineWHO Position paper. 2006;3(81):24-31.

3. Dinas Kesehatan Provinsi Jawa Timur. Kegiatan Sub PIN difteri sebagai bagian penanggulangan KLB difteri di Jawa Timur. (diunduh 16 Januari 2013). Tersedia dari: http://dinkes.jatimprov.go.id/ contentdetail/16/1/283/ayo_rame-rame ikut imunisasi sub pin difteri $\overline{\text { html }}$

4. Vitek $\mathrm{CR}$, Wharton $\bar{M}$. Diphtheria toxid. Dalam: Plotkin S, Orenstein W, Offit $\mathrm{P}$, penyunting. Vaccine. Edisi ke-5. Pennsylvania: Elsevier; 2008. hlm.139-56.

5. Muchlastriningsih E. Penyakit-penyakit menular yang dapat dicegah dengan Imunisasi di Indonesia. Cermin Kedokteran Indonesia. 2005;148(1):5-11.

6. Food and Drug Administration. Guidance for industry: toxicity grading scale for healthy adult and adolescent volunteers enrilled in Preventive Vaccine Trials, September 2007.

7. Department of Vaccines and Biologicals World Health Organization. Supplementary information on vaccine safety; Part 2: Background rates of adverse events following immunization. Geneva: WHO; 2000;23-6.

8. Wassilak SGF, Roper MH, Kretsinger K, Orenstein WA. Tetanus toxoid. Dalam: Plotkin S, Orenstein W, Offit P, penyunting. Vaccine. Edisi ke-5. Pennsylvania: Elsevier; 2008. hlm. 805-40.

9. Deacon SP, Langford DT, Shepherd WM, Knight PA. A comparative of clinical study of adsorbed tetanus vaccine and adult type tetanus diphtheria vaccine. J Hyg (Lond). 1982;89(3):513-9.

10. Fadlyana E, Rusmil K, Garna H, Bachtiar NS. Immunogenicity and safety of diphtery tetanus vaccine on teenagers to prevent reemerging disease in Indonesia. Ind J Appl. Sci. 2011;1(2):134-42.

11. Viella A, Dal-RE R, Simo D, Garcia-Corbeira P, Diego P, Bayas JM. Reactogenicity profile of tetanus-diphtheria (adult type) vaccine: results of a naturalistic study performed at an adult vaccination center. J Clin Phar. 2000;40(1):1267-73.

12. Lee SY, Kwak GY, Nam CH, Kom JH, Hur JK, Lee KY, dkk. Immunogenicity and safety of diptheria-tetanus vaccine in pre-adolescent and adolescent South Koreans. Vaccine. 2009;27(24):3209-12.

13. Bitragunta S, Murhekar MV, Chakravarti A, Verma V, Namjoshi GS, Parekh SS, dkk. Safety and immunogenicity of single dose of tetanus-diphtheria (Td) vaccine among non/partially immune achildren against diphtheria and or tetanus, Hyderabad, India 2007. Vaccine. 2010;28(37):5934-8.

14. Handayani S, Yuwono SS, Siburian F, Prijanto M. Status kekebalan anak terhadap difteri dan tetanus pada usia 5-6 tahun setelah imunisasi DT 1 dosis. Litbangkes, Digital Library, JKPKBPPK 2002. (diunduh 16 Januari 2013). Tersedia dari: http://grey. litbang.depkes.go.id/gdl.php?mod=browse \& op=read\&id=jkpkbppk-gdl-res-1998-sarwo433-antibodies.Rum renis ipsam et 